\title{
Pan(dem)ic Reactions in Turkish Stock Market: Evidence from share repurchases
}

\author{
Burak Pirgaip ( $\square$ burakpirgaip@hacettepe.edu.tr) \\ Hacettepe University https://orcid.org/0000-0001-8870-8502
}

\section{Research Article}

Keywords: Share repurchases, COVID-19, pandemic, event study, market reaction

Posted Date: September 18th, 2020

DOI: https://doi.org/10.21203/rs.3.rs-79999/v1

License: (c) (i) This work is licensed under a Creative Commons Attribution 4.0 International License. Read Full License

Version of Record: A version of this preprint was published at Eurasian Economic Review on May 5th, 2021. See the published version at https://doi.org/10.1007/s40822-021-00173-6. 


\section{Abstract}

Share repurchases have been widely used in global markets for years for various purposes such as to pay out cash, to stabilize stock prices, and so on. However, their use has recently been challenged due to the economic and financial uncertainty imposed by the COVID-19 outbreak. Not only governments have put bans or restrictions on the repurchasing transactions but also some major companies themselves have suspended their buyback programmes to preserve cash. On the other hand, repurchase activity has manifested itself in Turkish capital markets somewhat unexpectedly under uncertain market conditions. This study is one of the first attempts to explore the impact of share repurchase transactions on stock returns in an emerging market severely hit by COVID-19. Event study analyses reveal that market reaction to repurchase activity in the aftermath of the pandemic declaration of March 11, 2020 was significantly positive. Moreover, short-term stock performance of repurchasing firms was far greater than that of their non-repurchasing peers. These results have important policy implications in terms of corporate payout decisions which have recently been challenged by the new coronavirus.

\section{Introduction}

Stock markets that have already been showing a sharp declining trend for some time under the uncertainty of the COVID-19 outbreak, literally collapsed almost everywhere with the declaration of pandemic alert on March 11,2020. On that day, the "fire" spread very fast from one stock exchange to another. S\&P500 suffered its quickest descent into bear market. Nikkei225 and FTSE100 plunged as much as $10 \%$. In France and Germany, indexes cratered more than $12 \%$ and in Italy the figure was $16,9 \%$. The "fear" also manifested itself in the surge of the CBOE Volatility Index, i.e. VIX, which hit historically highest levels[1]. The situation was even worse in many emerging markets. For example, MSCI Emerging Markets index lost 10,5\%, while individually, South Africa and Brazil stocks closed down nearly $10 \%$ and $15 \%$, respectively and circuit breakers were triggered in many markets including South Korea, Thailand and Philippines.

The pandemic shock waves immediately spilled over into Borsa Istanbul, the Turkish Stock Exchange, as well. Turkey's benchmark stock index closed the day with a $7,26 \%$ decline. In the aftermath of the pandemic designation, the stock market tried to achieve recovery to some extent by means of governmental actions, but the damage was so severe that the attempts were not worthy of note. In these circumstances, some of the companies interestingly started to announce to buy back their shares as a preventive measure against plummeting prices. This was interesting for two reasons. First, although signalling or undervaluation is the most well-known motive attributed to share repurchases[2], one might justifiably argue that the main motivation in these times of unprecedented turmoil, would rather be holding more cash (Pirgaip and Dinçergök, 2019). Indeed, repurchase actions in the vast majority of countries were cancelled by the firms[3] or restricted by the regulatory bodies[4]. Given this, it was somewhat contrary to the expectations in the market where investors were frustrated with the uncertainty regarding the COVID-19. Second, Turkish government, as part of an omnibus bill, emphasized the importance of the preservation of companies' equities and imposed severe limitations on the amount of cash dividends[5]. Another common aspect of share repurchases is that they are substitutes[6] to cash dividends (Grullon and Michaely, 1992; Jiang et al., 2013). Yet, the government did not intervene in share repurchase decisions of firms. Conversely, Capital Markets Board[7] removed regulatory constraints on the share repurchase transactions for publicly listed companies (CMB, 2020). This was contradictory in that a company, which would not be entitled to distribute a restricted level of cash, would be able to buy its shares back at the same amount.

For these reasons, the recent share repurchase activity in Turkey is worth to be further investigated in order to explore the market reaction towards repurchase events under COVID-19 conditions. In this context, we employ an event study methodology to analyze the investor behaviour. Empirical results suggest that repurchase transactions had significantly positive effects on stock prices. This finding is robust when repurchasing firms are compared with their non-repurchasing peers.

Our paper fills a gap in the contemporaneous work on firms and the COVID-19 crisis and contributes to the literature on how repurchases are used in distressed times. The structure of the paper is as follows. Section 2 outlines recent literature on the impact of COVID-19 on stock markets. Section 3 describes the data and methodology employed in the study. Section 4 presents the empirical results and Section 5 concludes.

[1] According to DeCambre (2020) the move for the VIX induced by the global pandemic almost tripled its move at the same point in 2008, when the global financial crisis broke out.

[2] See Bhattacharya (1979), Vermaelen (1981), Vermaelen (1984), Lakonishok and Vermaelen (1990), Comment and Jarrell (1991), and Persons (1997).

[3] Goldman Sachs, JPMorgan Chase, Morgan Stanley, Citigroup, Bank of America are some of the major repurchasers in the US market which suspended their buyback programs. According to Goldman Sachs, share repurchases will decline by $50 \%$ to $\$ 371$ billion during 2020 (Kilgore, 2020 ). In the non-financial sector, General Motors and Ford Motor Company are the leading ones that announced the deferral of share repurchase programmes (Sheth, 2020). 
[4] In the US, for instance, companies that receive federal aid were not able to repurchase shares (Fox, 2020).

[5] The regulation (Law No. 7244, Date: 17.04.2020) required that the amount of cash dividends that can be distributed until 30.09 .2020 shall not exceed $25 \%$ of the net profit generated in 2019; profits of the previous year(s) or free reserve funds cannot be subject to any distribution; and the board of directors shall not be authorised by the general assembly for the distribution of advance dividends (Şenocak and Ak, 2020).

[6] Note that, there is also one strand of literature arguing that share repurchases complement cash dividends (Dittmar, 2000; Jagannathan and Stephens, 2003).

[7] Capital Markets Board of Turkey is the public authority responsible for regulating the Turkish securities markets with functions analogous to those of the SEC.

\section{Literature Review}

There is a growing body of literature focusing on the impact of COVID-19 on stock markets. Zhang et al. (2020) point out the great uncertainty caused by the pandemic which have led to increased volatility and unpredictability in the markets. Ashraf (2020) scrutinizes the stock market response to the COVID-19 confirmed cases and deaths and finds that the market reaction to the growth in confirmed cases was significantly negative while response to the growth in deaths were weak. Okorie and Lin (2020) investigate the fractal contagion effect of the COVID-19 pandemic on the stock market returns and volatilities by using Detrended Moving Cross-Correlation Analysis and Detrended Cross-Correlation Analysis techniques. Over a sample of top 32 COVID-19 affected economies, the authors provide evidence for a short-lived fractal contagion effect revealing the comovements among various stock markets. Ramelli and Wagner (2020) signify the fever in the stock markets as the virus spread to Europe and the US. Similarly, Ali et al. (2020) report that, as the virus moved from epidemic to pandemic as well as from China to Europe and the US, panic in the stock markets increased. However, Zaremba et al. (2020) demonstrate that it is the government interventions that increase the volatility in the stock markets.

Nevertheless, repurchase activity and COVID-19 linkage has not been fully explored yet. Instead, there are traces of literature concerning dividend policy decisions of firms under uncertainty. For instance, Pettenuzzo et al. (2020) examine how the pandemic affected firms' decisions to suspend dividends. One of the key findings in their work is that the market reaction to the huge number of dividend payment suspensions was strongly negative, whereas investors perceived dividend reductions as a positive sign of financial strength. The authors also argue that dividend suspensions have profound impact on the expected future dividend growth. Cejnek et al. (2020) shed light on the issue from the standpoint of the firms' future cost of capital and articulate that investors required additional compensation for negative co-skewness in addition to the pure beta risk. In another study, Fahlenbrach et al. (2020) find no evidence that firms with higher payouts are affected more adversely by the COVID-19 crisis implying that payouts do not have to reduce financial flexibility.

\section{Data And Methodology}

Stock repurchase data may reflect the findings of the recent literature in the sense that firms might have made used of the flexible nature of repurchases in their struggle with the pandemic to send positive signals to the market. In that respect, Figure 1 portrays the pattern in repurchase transactions in Borsa Istanbul in Year 2020.

As Part A of Figure 1 shows, while the repurchase activity has been only incidental before the pandemic alert, it skyrocketed within a very short period of time as a sudden reaction to the panic situation in the market. Number of firms that repurchase stock had a fivefold increase and the Turkish Lira (TRY) amount of repurchase transactions surged by a thousand percent in a few days. This happening coincides with the decreasing trend, which was around $-1,88 \%$ on daily basis, in the stock exchange as depicted in the Part B of Figure 1. More specifically, the trading days when high number/volume of repurchases was observed were also the ones when XU100, i.e. the benchmark index, was in a free-fall. For instance, share repurchases overflowed exactly on March 17, 2020, following the day the market dropped by 8,07\%.

Figure 1 also implies that the repurchasing activity died out in about 15 trading days as the market started to stabilize. In this 15 -trading day-period following the pandemic declaration, 19 companies (ironically to respond to COVID-19), announced and repurchased their own stocks. Table 1 provides brief information about these companies and their repurchasing activities.

\section{Table 1: Repurchasing companies}




\begin{tabular}{|llllllllll|}
\hline Sec. & \multicolumn{2}{l}{ Non-Financial } & \multicolumn{7}{l|}{ Financial } \\
\hline Ind. & Mfg. & $\begin{array}{l}\text { Rest. } \\
\text { \&Hotels }\end{array}$ & Tech. & Hld. & VCITs & Banks & REITs & SITs & TOTAL \\
\# of firms & 5 & 1 & 3 & 1 & 2 & 2 & 2 & 3 & 19 \\
\hline \% of rep. amt. & 7 & 1 & - & 19 & 4 & 58 & 9 & 2 & $100 \%$ \\
\hline \# of rep. days & 11 & 9 & 3 & 9 & 11 & 3 & 2 & 4 & $\mathbf{5 2}$ \\
\hline
\end{tabular}

Notes: This table demonstrates information regarding the companies that repurchased stocks after March 11, 2020. Mfg.: Manufacturing; Rest.\&Hotels: Restaurants and Hotels; Tech.: Technology; HId.:Holdings; VCITs: Venture Capital Investment Trusts; REITs: Real Estate Investment Trusts; SITs: Securities Investment Trusts.

As Table 1 suggests, financial companies outweigh non-financial ones in conducting repurchasing activities in the period of COVID-19 pandemic alert. Banks have the largest share of the total repurchased amount, while manufacturing firms and venture capital investment trusts are the most frequent repurchasers.

We analyze the short-term stock market response to share repurchase transactions of the sample of 19 companies by employing standard event study methodology. The method requires the calculation of abnormal returns defined as the deviation from the expected return as formulated in Equation (1) below:

$$
A R_{i t}=R_{i t}-E R_{i t}
$$

where $A R_{i t}$ is the abnormal, $R_{i t}$ is the actual and $E R_{i t}$ is the expected return of the firm $i$ in time $t$. $E R_{i t}$ is calculated by means of the following commonly used market model:

$$
R_{i t}=a+\beta x R_{m t}
$$

A proper determination of estimation and event windows is of utmost importance in event studies, since there is a trade-off between a shorter and longer window of estimation mainly due to confounding events. Nonetheless, previous research is polyphonic in this regard, particularly in the case of emerging markets. A detailed review of literature for event studies in Turkish market[8] reveals that an estimation window of 100 trading days $[-110,+11]$ and an event window of 21 trading days $[-10,+10]$ would be plausible[9]. Note that, although these windows are long enough to capture the signalling effects and short enough to exclude confounding events, we generate abnormal returns for several event windows with different lengths as well. Moreover, since frequently repurchasing firms would bias the analysis, it is assumed that consecutive repurchases are deemed as a single transaction and the transaction in the first business day in the event window is included in the calculations (Zhang, 2005).

As suggested by Equation (2), we regress the actual share returns $\left(R_{i t}\right)$ on the market portfolio returns $\left(R_{m t}\right)$ for the estimation period. We obtain the parameter estimates $\left(\alpha\right.$ and $\beta$ ) from these regressions and compute the expected returns $\left(E R_{i t}\right)$ for each day in the event period in line with Equation (1). XU100 index is used as the market proxy since it represents the whole market in terms of market capitalization. Rate of returns are calculated upon the logarithmic differences of the closing price at a single day and that of the previous day. Cumulative abnormal returns (CAR) are computed as follows:

$$
C A R_{i t}=\sum_{t=1}^{n} A R_{i t}
$$

Finally, we derive average abnormal returns (AAR) and cumulative abnormal returns (CAAR) by taking the mean of the summed $A R_{i t}$ and $C A R_{i t}$ of the sample firms in the event period and employ parametric and non-parametric tests for the significance of both returns. Data used in the event study regarding stock prices and share repurchase transactions are retrieved from Borsa Istanbul and Public Disclosure Platform[10], respectively. 
[8] Please see Basdas and Oran (2014) and the references therein.

[9] From a legal point of view, this also coincides with the specific regulations of Capital Markets Board, which require a 6-month period as a proxy for sound and efficient price formation in Turkish capital markets.

[10] All public disclosure materials should be published in the Public Disclosure Platform (PDP), a 7/24 electronic system through which electronically-signed notifications of companies are disclosed. The PDP website is accessible at https://www.kap.org.tr/en/.

\section{Results}

We summarize the descriptive statistics for stock returns in two dimensions. First, we group the mean stock returns as "before-and-after" the pandemic alert. Second, we report them as "before-and-after" the respective repurchase transactions of the companies. Since some companies have started to repurchase soon after, even on the same day of, the pandemic declaration, the period after pandemic alert and the period after repurchase transactions unavoidably overlap. Yet, such grouping is useful to have an insight on the impact of repurchases in time. These summary statistics are presented in Table 2.

Table 2. Descriptive statistics

\begin{tabular}{|llllllll|}
\hline & Mean & Med. & St.Dev. & Min. & Max. & Skew. & Kurt. \\
\hline Panel A: Pandemic Alert & & & & & & & \\
\hline Mean Stock Returns & & & & & & & \\
\hline Before & -0.021 & -0.027 & 0.043 & -0.082 & 0.044 & 0.232 & 1.975 \\
\hline After & 0.000 & 0.000 & 0.049 & -0.123 & 0.084 & -0.627 & 3.474 \\
\hline Mean XU100 Returns & & & & & & & \\
\hline Before & -0.011 & -0.010 & 0.030 & -0.060 & 0.040 & -0.026 & 2.118 \\
\hline After & -0.003 & -0.001 & 0.031 & -0.081 & 0.060 & -0.822 & 4.235 \\
\hline Panel B: Repurchase Activity & & & & & & & \\
\hline Mean Stock Returns & & & & & & & \\
\hline Before & -0.037 & -0.038 & 0.023 & -0.075 & -0.001 & -0.011 & 2.474 \\
\hline After & 0.017 & 0.015 & 0.016 & -0.011 & 0.039 & -0.119 & 2.008 \\
\hline Mean XU100 Returns & & & & & & & \\
\hline Before & -0.019 & -0.018 & 0.013 & -0.046 & -0.003 & -0.587 & 2.556 \\
\hline After & 0.001 & 0.004 & 0.013 & -0.023 & 0.015 & -0.796 & 2.339 \\
\hline
\end{tabular}

Notes: This table provides information regarding the descriptive features of the data. In Panel A, statistics regarding mean stock and XU returns are reported as before and after the pandemic declaration of March 11, 2020. In Panel B, same statistics are presented this time as before and after respective repurchase transactions.

It is apparent from Table 2 that mean stock returns increased on average both after the pandemic alert and repurchase transactions, but the increase after the latter (from $-3,7 \%$ to $1,7 \%$ ) appears to be more dramatic. A slight decrease in the volatility in returns (from $2,3 \%$ to $1,6 \%$ ) is observed following repurchase transactions, which is the opposite (an increase from $4,3 \%$ to $4,9 \%$ ) in the case of pandemic alert. This is also confirmed by the narrowing range of returns after firms have started to repurchase. Skewness and kurtosis figures after repurchases are lower as well. These preliminary results may be read as the initial impact of repurchases on stock returns was not positive enough to reverse the pressurized market conditions, while it revealed its significance over time as more companies took part in the activity and ultimately helped the market recover.

To draw more precise inferences, we report the results of the event study in Table 3. Both parametric (Columns 2-5) and non-parametric (Column 6) test results indicate that repurchase transactions had significantly positive effects on stock returns. Average abnormal returns on the event day (Day 0) and in some post-event days (Day 2, Day 3, Day 6 and Day 8) provide strong evidence that market reacted positively to repurchase events (Column 3). Such positive reactions were so reflected in stock prices that the soaring levels of cumulative abnormal returns reverted back almost to their earlier values (Column 4). Typically, significant abnormal returns in the pre-event period would be considered as signs of information leakage in the market; however, it would be more reasonable to relate the entire negativity in stock returns with the unfavourable market conditions due to pandemic. 
Table 3: Abnormal returns surrounding the repurchase date

\begin{tabular}{|c|c|c|c|c|c|}
\hline Day & AAR(\%) & $t($ AAR $)$ & CAAR(\%) & $t(\mathrm{CAAR})$ & Wilcoxon Test (z) \\
\hline-10 & -2.179 & $-2.587 * \star \star$ & -2.179 & 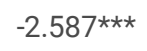 & $-2.213^{\star \star}$ \\
\hline-9 & -0.989 & -0.933 & -3.168 & $-2.129 * \star$ & -1.127 \\
\hline-8 & -3.310 & $-4.979 * \star *$ & -6.478 & $-4.098 * \star \star$ & 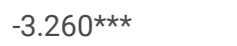 \\
\hline-7 & -4.231 & $-4.159 * * *$ & -10.710 & $-5.554 * \star \star$ & $-3.260 * * *$ \\
\hline-6 & 0.159 & 0.177 & -10.551 & $-4.752^{\star \star *}$ & 0.563 \\
\hline-5 & -1.915 & $-2.468 * \star$ & -12.466 & $-4.529 * \star \star$ & $-2.294 \star \star$ \\
\hline-4 & -2.428 & $-3.216^{\star \star *}$ & -14.894 & $-4.978 * * \star$ & $-2.736^{\star * *}$ \\
\hline-3 & -0.555 & -0.881 & -15.449 & $-4.902^{\star \star \star}$ & -0.845 \\
\hline-2 & -2.552 & $-3.076 * \star \star$ & -18.002 & $-5.015^{\star \star \star}$ & $-2.535^{\star \star}$ \\
\hline-1 & 0.467 & 0.668 & -17.535 & $-4.567 * \star \star$ & 1.248 \\
\hline 0 & 2.194 & $1.835^{\star}$ & -15.341 & $-3.488 * \star \star$ & $1.690 *$ \\
\hline 1 & 0.856 & 0.978 & -14.485 & $-3.600 * * *$ & $1.811^{*}$ \\
\hline 2 & 2.236 & $2.724^{\star \star \star}$ & -12.249 & $-3.235^{\star \star \star}$ & $2.374^{\star \star}$ \\
\hline 3 & 2.481 & $4.215^{\star \star \star}$ & -9.768 & $-2.640 * * *$ & $3.582^{\star \star \star}$ \\
\hline 4 & 0.383 & 0.339 & -9.385 & $-2.788 * \star \star$ & -0.121 \\
\hline 5 & 0.354 & 0.338 & -9.031 & $-2.680 * * \star$ & 0.121 \\
\hline 6 & 2.472 & $2.500 * \star$ & -6.559 & -1.870 * & $2.374^{\star \star}$ \\
\hline 7 & -0.081 & -0.094 & -6.640 & $-1.785^{\star}$ & -0.483 \\
\hline 8 & 1.277 & $1.800 *$ & -5.363 & -1.413 & 1.489 \\
\hline 9 & 0.135 & 0.218 & -5.228 & -1.352 & -0.483 \\
\hline 10 & 1.360 & 1.613 & -3.868 & -1.003 & 1.368 \\
\hline Window & CAAR(\%) & $t(\mathrm{CAAR})$ & Window & CAAR(\%) & $t(\mathrm{CAAR})$ \\
\hline$[-5,-1]$ & -6.984 & $-3.079 * \star \star$ & {$[0,+1]$} & 3.050 & $1.977^{\star \star}$ \\
\hline$[-2,0]$ & -2.552 & $-3.076 * \star \star *$ & {$[0,+5]$} & 8.503 & 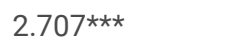 \\
\hline$[-1,0]$ & 0.467 & 0,668 & {$[+1,+5]$} & 6.310 & 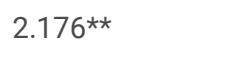 \\
\hline$[-1,+1]$ & 3.517 & 1.887* & {$[+1,+10]$} & 11.473 & $2.989 * \star \star$ \\
\hline
\end{tabular}

Notes: This table displays the effects of share repurchases. Day 0 is the repurchase (event) date. AAR(\%) and CAAR(\%) abnormal return and cumulative abnormal return on average. $t(A A R)$ and $t(C A A R)$ represent the t statistics. Non-parametric Wilcoxon signed-rank test statistics show

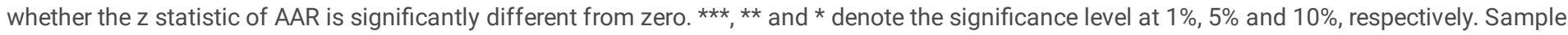
includes 19 repurchasing firms.

As laid out at the bottom of Table 3, the turnaround in the stock returns can be identified easily. Starting from the repurchase event, CAAR figures that are negative in the pre-event period switch to positive first and then gain gradual significance throughout the post-event period in a persistent manner. The graphical representation of CAAR surrounding the repurchase event is shown in Figure 2. The CAAR graph implies that stock market has welcomed share repurchases probably because investors had the perception that repurchasing firms were healthy enough to invest in. Put alternatively, firm managers have been successful in using repurchases as a signalling instrument for the purpose of price stabilization.

At this juncture, it is worth to note that the increase in stock returns might have resulted from factors other than repurchase transactions. An overall recovery, perhaps led by those factors such as government subsidies, liquidity enhancements, precautionary actions, news etc., in XU100 is already observed as can be seen from Part B of Figure 1. Therefore, the contribution of share repurchases in this context is arguable. One solution would be to regress abnormal returns on macroeconomic as well as firm-specific factors; however, the small sample size would hinder the reliability of 
parameter estimates. More prominently, we build our analysis on a very short period of time and use daily stock return data to address the short-term impact of COVID-19 in capital markets. In that sense, a regression model may not be suitable because most of the data pertaining to other factors would have at least monthly, if not quarterly, frequency.

Thus, as a robustness check, we compare the market reaction to COVID-19 in the case of repurchasing firms with that of non-repurchasing firms. To this end, we match repurchasers with non-repurchaser peers[11] on the basis of size (total assets and market capitalization) and relative valuation (market-to-book and price-to-earnings) criteria. This approach is common in the previous literature[12]. One-to-one matching process ends up with 19 repurchasers and 19 non-repurchasers. At the next step, we use event study methodology to observe the market reaction to pandemic alert of March $11,2020$ for both types of firms. The only difference in the methodology is that we expand the event window as 31 trading days [-10, +20$]$ in order to correspond with the fade-away of the repurchasing activity in the market. By doing so, the impact of repurchases would be observable to its end. Results are given in Table 4.

Table 4: Abnormal returns surrounding the pandemic alert 


\begin{tabular}{|c|c|c|c|c|c|c|c|c|c|c|c|}
\hline \multicolumn{6}{|c|}{ Repurchasing Firms } & \multicolumn{6}{|c|}{ Non-Repurchasing Firms } \\
\hline Day & $\operatorname{AAR}(\%)$ & $t(A A R)$ & CAAR(\%) & $t($ CAAR) & $\begin{array}{l}\text { Wilcoxon } \\
\text { Test (z) }\end{array}$ & Day & AAR(\%) & $t($ AAR $)$ & CAAR(\%) & $t($ CAAR) & $\begin{array}{l}\text { Wilcoxon } \\
\text { Test (z) }\end{array}$ \\
\hline-10 & -1.275 & $-2.440 * \star$ & -1.275 & $-2.440 * \star$ & $-2.093^{\star \star}$ & -10 & -1.953 & $-3.649 * \star \star$ & -1.953 & $-3.649 \star \star \star$ & $-3.114 * \star *$ \\
\hline-9 & -2.479 & $-4.675^{\star \star \star}$ & -3.754 & $-4.557 \star \star \star$ & $-3.380 * \star \star$ & -9 & -0.905 & -1.373 & -2.858 & 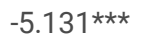 & $-1.982^{\star \star}$ \\
\hline-8 & -1.377 & $-2.013^{\star \star}$ & -5.131 & 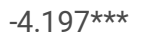 & $-1.932^{\star}$ & -8 & -1.917 & $-3.264^{\star \star \star}$ & -4.775 & $-5.822^{\star \star \star}$ & $-2.765^{\star \star \star}$ \\
\hline-7 & 2.779 & $4.252^{\star \star \star}$ & -2.352 & $-2.086 \star \star$ & 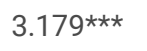 & -7 & 3.527 & $3.919 \star \star \star$ & -1.247 & -1.348 & $3.201 * \star \star$ \\
\hline-6 & -0.008 & -0.018 & -2.359 & $-2.109 \star \star$ & 0.000 & -6 & -0.514 & -0.672 & -1.761 & -1.640 & -0.501 \\
\hline-5 & -2.010 & $-4.247 * * \star$ & -4.369 & $-3.411 * \star \star$ & $-3.099 * * *$ & -5 & -2.616 & $-3.356^{\star \star \star}$ & -4.377 & $-3.433^{\star \star \star}$ & $-2.678 * \star *$ \\
\hline-4 & -0.827 & -1.410 & -5.197 & $-3.549 * \star \star$ & $-2.455^{\star \star}$ & -4 & -0.632 & -1.381 & -5.009 & $-4.885^{\star \star \star}$ & $-1.764^{\star}$ \\
\hline-3 & -1.449 & $-3.163^{\star \star \star}$ & -6.646 & 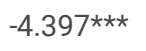 & 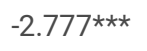 & -3 & -0.103 & -0.083 & -5.112 & $-3.443^{\star \star \star}$ & $-1.982^{\star \star}$ \\
\hline-2 & -2.621 & $-3.309 * \star *$ & -9.267 & $-4.789 * \star \star$ & $-2.656 * \star \star$ & -2 & -3.239 & $-2.899 * \star *$ & -8.351 & $-6.438 * \star \star$ & $-2.504^{\star \star}$ \\
\hline-1 & -1.397 & -1.168 & -10.664 & 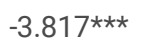 & -1.248 & -1 & -4.352 & 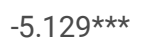 & -12.703 & $-7.491 * \star \star$ & $-3.462^{\star \star *}$ \\
\hline 0 & -3.799 & $-5.078 * \star \star$ & -14.4632 & $-4.790 * \star \star$ & $-3.380 * \star \star$ & 0 & -6.320 & $-4.332^{\star \star \star}$ & -19.023 & $-8.225^{\star \star \star}$ & $-2.896 * \star \star$ \\
\hline 1 & -4.902 & $-3.858^{* * \star}$ & -19.365 & $-5.167 * \star \star$ & $-2.978 * * *$ & 1 & -6.606 & $-7.146^{\star \star *}$ & -25.629 & $-8.783^{\star \star *}$ & $-3.593^{\star * *}$ \\
\hline 2 & 2.069 & $3.602^{\star \star \star}$ & -17.297 & 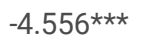 & 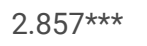 & 2 & 1.028 & 0.822 & -24.602 & $-7.788^{\star \star \star}$ & 1.241 \\
\hline 3 & -0.375 & -0.547 & -17.672 & $-4.198 * \star \star$ & -0.322 & 3 & -0.594 & -0.579 & -25.196 & $-8.069 * * \star$ & -1.067 \\
\hline 4 & -3.432 & $-2.965^{\star \star \star}$ & -21.104 & $-4.184^{\star \star \star}$ & $-2.495^{\star \star}$ & 4 & -4.457 & $-3.451 * \star \star$ & -29.652 & 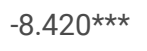 & $-2.591^{\star \star \star *}$ \\
\hline 5 & -1.463 & $-2.164^{\star \star}$ & -22.567 & $-4.185^{\star \star \star}$ & $-1.932^{\star}$ & 5 & -1.472 & -1.377 & -31.124 & $-8.027^{\star \star \star}$ & $-1.677^{*}$ \\
\hline 6 & -1.612 & $-2.187^{\star \star}$ & -24.179 & $-4.222^{\star \star \star}$ & $-2.213^{\star \star}$ & 6 & -1.128 & -0.876 & -32.253 & $-7.188^{* * *}$ & -0.893 \\
\hline 7 & 1.237 & $2.205^{\star \star}$ & -22.942 & $-4.274^{\star \star \star}$ & $2.334^{\star \star}$ & 7 & 2.485 & $3.751^{\star \star \star}$ & -29.767 & $-6.935^{\star \star \star}$ & $3.245^{\star \star \star}$ \\
\hline 8 & 0.916 & 0.666 & -22.026 & 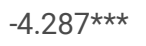 & 0.201 & 8 & -1.227 & -0.853 & -30.994 & 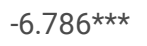 & -0.936 \\
\hline 9 & 1.747 & 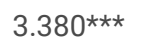 & -20.280 & $-4.187 * \star \star$ & 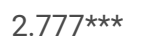 & 9 & 0.992 & 1.179 & -30.003 & $-6.709 * \star \star$ & $1.720 *$ \\
\hline 10 & 2.800 & $3.372 * \star \star$ & -17.480 & $-3.928 * \star \star$ & 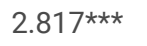 & 10 & 3.076 & $3.161^{\star \star \star}$ & -26.926 & 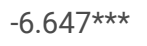 & $2.504 * \star$ \\
\hline 11 & 3.038 & $3.824 * \star \star$ & -14.441 & $-3.646 * \star \star$ & 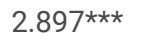 & 11 & 1.507 & 1.219 & -25.419 & $-6.396 * \star \star$ & 1.328 \\
\hline 12 & 1.274 & 1.405 & -13.167 & $-3.731 * \star \star$ & 0.926 & 12 & 2.278 & $1.817^{*}$ & -23.141 & 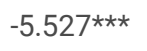 & $1.851^{*}$ \\
\hline 13 & -0.237 & -0.230 & -13.403 & $-3.724^{\star \star \star}$ & 0.161 & 13 & 0.158 & 0.121 & -22.984 & $-5.156^{\star \star \star}$ & 0.065 \\
\hline 14 & 3.615 & 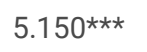 & -9.788 & $-2.784^{\star \star \star}$ & $3.662^{\star \star \star}$ & 14 & 2.645 & $2.158^{\star \star}$ & -20.338 & $-4.074^{\star \star \star}$ & $2.243^{\star \star}$ \\
\hline 15 & 0.379 & 0.501 & -9.409 & $-2.699 \star * \star$ & 0.040 & 15 & 0.604 & 0.449 & -19.734 & 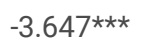 & -0.501 \\
\hline 16 & -0.752 & -0.870 & -10.161 & $-2.680 * \star \star$ & -1.207 & 16 & -2.067 & $-2.075^{\star \star}$ & -21.802 & 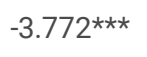 & $-2.286^{\star \star}$ \\
\hline 17 & -0.437 & -0.649 & -10.598 & $-2.594^{\star \star \star}$ & -1.408 & 17 & -1.802 & $-2.033^{\star \star}$ & -23.603 & $-3.782^{\star \star \star}$ & $-1.938^{*}$ \\
\hline 18 & 1.690 & $3.055^{\star \star \star}$ & -8.908 & $-2.303^{\star \star}$ & $2.616^{\star \star \star}$ & 18 & 0.960 & 1.070 & -22.644 & $-3.609 * * *$ & $1.894^{*}$ \\
\hline 19 & 0.127 & 0.211 & -8.780 & $-2.203^{\star \star}$ & -0.443 & 19 & -0.068 & -0.071 & -22.711 & $-3.605^{\star \star \star}$ & -0.24 \\
\hline 20 & 0.044 & 0.088 & -8.736 & $-2.097 * \star$ & -0.282 & 20 & -0.662 & -0.766 & -23.373 & $-3.669 * \star \star$ & -0.958 \\
\hline Window & CAAR(\%) & $t(C A A R)$ & Window & CAAR(\%) & $t(\mathrm{CAAR})$ & Window & CAAR(\%) & $t(\mathrm{CAAR})$ & Window & CAAR(\%) & $t(C A A R)$ \\
\hline$[-1,0]$ & -5.196 & $-3.658 * \star \star$ & {$[+1,+20]$} & 5.727 & 1.425 & {$[-1,0]$} & -4.352 & 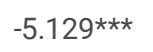 & {$[+1,+20]$} & -4.350 & -0.731 \\
\hline$[0,+1]$ & -8.701 & $-5.090 * * \star$ & {$[+2,+10]$} & 3.624 & $1.851^{\star}$ & {$[0,+1]$} & -12.926 & $-6.192^{\star \star \star}$ & {$[+2,+10]$} & -1.297 & -0.536 \\
\hline$[+1,+5]$ & -8.104 & $-2.459 * \star$ & {$[+10,+20]$} & 11.544 & 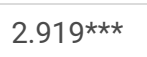 & {$[+1,+5]$} & -12.101 & $-4.665^{\star \star \star}$ & {$[+10,+20]$} & 6.629 & 1.070 \\
\hline$[+1,+10]$ & -3.016 & -1.171 & {$[+2,+20]$} & 10.629 & $2.507 * \star$ & {$[+1,+10]$} & -7.903 & -3.012 & {$[+2,+20]$} & 2.256 & 0.376 \\
\hline
\end{tabular}

Notes: This table displays the effects of pandemic declaration. Day 0 is the declaration (event) date. AAR(\%) and CAAR(\%) abnormal return and cumulative abnormal return on average. $t(A A R)$ and $t(C A A R)$ represent the t statistics. Non-parametric Wilcoxon signed-rank test statistics show 


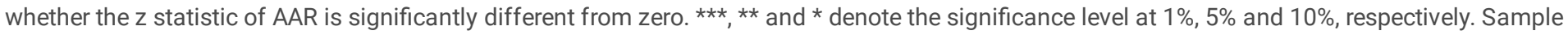
includes 19 repurchasing firms and 19 non-repurchasing firms.

Table 4 elucidates that the initial market reaction to the pandemic declaration was negative for both types of firms. However, as firms initiated their repurchase activities, repurchasing firm returns have shown a more profound increase than that observed in non-repurchaser stocks. It is evident that while the negative values of repurchaser CAAR substantially dropped in the post-event period, the decline in the negative CAAR that are pertinent to non-repurchasers was not that significant. Various event windows given in the lower part of Table 4 confirm these findings. In concrete terms, it was possible to generate significantly positive returns with the stocks of repurchasing firms in the post-declaration period as opposed to non-repurchasing firms. Figure 3 provides a striking view of what has happened to stock returns both before and after the pandemic alert.

As Figure 3 manifests, even though repurchasing and non-repurchasing firm stocks moved closely together in the pre-event period, they started to diverge from each other as of the event day and the difference between the two got bigger in the post-event period when repurchase transactions became frequent. Table 5 reveals the statistical significance of this difference.

Table 5: Tests of differences in means

\begin{tabular}{|lllll|}
\hline & Pre-event period & \multicolumn{3}{c|}{ Post-event period } \\
\hline $\mathrm{H}_{0}$ & $\mathrm{CAAR}_{\mathrm{R}}=\mathrm{CAAR}_{\mathrm{NR}}$ & $\mathrm{CAAR}_{\mathrm{R}}>\mathrm{CAAR}_{\mathrm{NR}}$ & $\mathrm{CAAR}_{\mathrm{R}}=\mathrm{CAAR}_{\mathrm{NR}}$ & $\mathrm{CAAR}_{\mathrm{R}}>\mathrm{CAAR}_{\mathrm{NR}}$ \\
\hline p-value & 0.847 & 0.577 & 0.000 & 0.000 \\
\hline
\end{tabular}

Notes: This table presents tests of differences in mean CAAR of repurchaser $\left(C_{A A R}\right)$ and non-repurchaser $\left(C A A R_{N R}\right)$ firms' $^{\prime}$ stocks.

According to Table 5, CAAR of repurchasing firms are significantly higher than the ones of non-repurchasing firms in the post-event period, while the null hypothesis of pre-event CAAR are equal cannot be rejected. Eventually, we conclude that repurchase transactions were effective in stifling panic in the aftermath of COVID-19 pandemic alert in the market, especially when compared with the firms did not repurchase their stocks.

[11] Since they are peers, they are already industry-matched. Peer companies data are obtained from Bloomberg.

[12] See Jagannathan and Stephens (2003), Lie (2005), and Andriosopoulos and Hoque (2013).

\section{Conclusion}

The new coronavirus has caused a great threat not only to the health of the human being but also to the wealth of the investment community. Stock markets worldwide tumbled and the fear spilled over very quickly resulting in historic declines in return levels. In such a panic, a few companies in Turkish stock market started to repurchase their own stocks with an intention to stabilize their prices. In line with the analysis results, these transactions appear to be successful in supporting prices insomuch that they had a significant contribution in the recovery of the market.

These results offer at least three policy implications. First, policymakers should consider the potential impacts of restricting corporate payouts. Undoubtedly, it is vital to take precautionary actions to preserve cash; however, this does not necessarily mean to neglect the importance of the firms' future cost of capital. Having acknowledged the sticky nature of cash dividends (Ha et al., 2017), it would be reasonable to benefit from the flexibility of share repurchases in reducing the cost of capital (Green and Hollifield, 2003). If repurchase activity is also banned or restricted just as in the case of dividend payouts, the cost of flexibility may increase (Bonaimé et al., 2016) which in turn would lead to an increase in cost of capital. Second, one of the most effective policies for decision-makers in dealing with the uncertainty in the market is to mind the signalling power of payout policies. Stock markets value better-than-expected dividend practices (Pettenuzzo et al., 2020). Hence, it would be more prudent to continue to pay dividends or to repurchase stocks to some extent rather than suspending their execution as a whole. Certainly not all companies would have the capability to sustain their payout policies, but the ones which have adequate resources and are financially flexible would at least use the informational power of payouts as a signalling instrument to retain and attract investors even in depressing markets. Lastly, share repurchases are attractive to investors provided that they do not jeopardize company's financial situation. The wide use of repurchases in global markets[13] should be closely monitored by regulatory bodies in case they may be used to inflate stock prices artificially rather than allocating cash in order to maintain the business operations (Bhattacharya and Jacobsen, 2016). This is of particular importance in designing stimulus packages which include financial support for companies to survive and recover through the pandemic.

This study is not without limitations. One is pertinent to the small sample size. Only a few repurchasing firms may not represent the impact of stock repurchases in the stock market. But, note that, these companies bought their stocks quite frequently. Thus, the number/amount of repurchases may 
override the number of repurchasers in our case. Our results are also subject to the usual limitations of event studies. That we focus on how markets reacted to repurchases has the shortcoming to neglect other potential factors that might have played a role on the overreaction and underreaction of the market. For future research, we leave further analyses focusing on the relationship between the repurchasing activity and the financial situation of firms in order to understand better how share repurchases contribute to firm value.

[13] For instance, S\&P500 repurchases for 2019 totalled \$728.7 billion (Crabb, 2020).

\section{Declarations}

Funding: Not applicable.

Conflicts of interest/Competing interests: We have no conflict of interest to declare.

Availability of data and material: Available upon on request.

Code availability: Available upon on request.

JEL Codes: G14, G15, G18

\section{References}

Ali, M., Alam, N., \& Rizvi, S. (2020). Coronavirus (COVID-19)-An epidemic or pandemic for financial markets. Journal of Behavioral and Experimental Finance, 27.

Andriosopoulos, D., \& Hoque, H. (2013). The determinants of share repurchases in Europe. International Review of Financial Analysis, $27,65-76$.

Ashraf, B. (2020). Stock markets' reaction to COVID-19: Cases or fatalities? Research in International Business and Finance, 54.

Basdas, Ü., \& Oran, A. (2014). Event studies in Turkey. Borsa Istanbul Review, 14(3), 167-188.

Bhattacharya, S. (1979). Imperfect information, dividend policy, and "the bird in the hand" fallacy. Bell Journal of Economics, 10, $259-270$.

Bhattacharya, U., \& Jacobsen, S. (2016). The share repurchase announcement puzzle: Theory and evidence. Review of Finance, 20(2), 725-758.

Bonaimé, A., Hankins, K., \& Jordan, B. (2016). The cost of financial flexibility: Evidence from share repurchases. Journal of Corporate Finance, 38, 345-362.

Cejnek, G., Randl, O., \& Zechner, J. (2020). The Covid-19 Pandemic and Corporate Dividend Policy. Available at SSRN 3576967.

CMB. (2020, 03 23). Announcement on Measures with Respect to Capital Markets in Response to the COVID - 19 Outbreak. Retrieved 0622,2020 , from Capital Markets Board of Turkey: https://www.cmb.gov.tr/Duyuru/Dosya/2020323/0

Comment, R., \& Jarrell, G. (1991). The relative signalling power of Dutch-auction and fixed price self-tender offers and open-market share purchases. Journal of Finance, 46, 1243-1271.

Crabb, J. (2020, 04 03). Covid-19 illuminates corporate buyback issues. International Financial Law Review.

DeCambre, M. (2020, 03 12). Chart of Wall Street's 'fear' index in 2020 illustrates how unhinged stock markets have been over coronavirus compared to the 2008 crisis. Retrieved 06 20, 2020, from MarketWatch: https://www.marketwatch.com/story/this-chart-of-the-stock-markets-fear-index-in-2020illustrates-how-unhinged-markets-have-been-over-coronavirus-compared-to-the-2008-crisis-2020-03-10

Dittmar, A. (2000). Why do firms repurchase stock? Journal of Business, 73(3), 331-355.

Fahlenbrach, R., Rageth, K., \& Stulz, R. (2020). How Valuable is Financial Flexibility when Revenue Stops? Evidence from the COVID-19 Crisis. NBER Working Paper.

Fox, J. (2020, 04 01). Critics of Stock Buybacks Will Outlast Coronavirus. Retrieved 06 21, 2020, from Bloomberg:

https://www.bloomberg.com/opinion/articles/2020-04-01/coronavirus-aid-ban-on-stock-buybacks-won-t-stop-criticism

Green, R., \& Hollifield, B. (2003). The personal-tax advantages of equity. Journal of Financial Economics, 67(2), $175-216$.

Grullon, G., \& Michaely, R. (1992). Dividends, share repurchases, and the substitution hypothesis. Journal of Finance, 57(4), $1649-1684$. 
Ha, C., Im, H., \& Kang, Y. (2017). Sticky dividends: a new explanation. Finance Research Letters, 23, 69-79.

Jagannathan, M., \& Stephens, C. (2003). Motives for multiple open-market repurchase programs. Financial Management, $32,71-91$.

Jiang, Z., Kim, K., Lie, E., \& Yang, S. (2013). Share repurchases, catering, and dividend substitution. Journal of Corporate Finance, 21 , 36-50.

Kilgore, T. (2020, 04 07). More stockmarket volatility, less buying the dip, and slower earnings per share growth ahead, Goldman Sachs says. Retrieved 06 21, 2020, from MarketWatch: https://www.marketwatch.com/story/more-stockmarket-volatility-less-buying-the-dip-and-slower-earningsper-share-growth-ahead-goldman-sachs-says-2020-04-07

Lakonishok, J., \& Vermaelen, T. (1990). Anomalous price behavior around repurchase tender offers. Journal of Finance, $45,455-477$.

Lie, E. (2005). Operating performance following open market share repurchase announcements. Operating performance following open market share repurchase announcements, 39(3), 411-436.

Okorie, D., \& Lin, B. (2020). Stock Markets and the COVID-19 Fractal Contagion Effects. Finance Research Letters, In Press, Journal Pre-proof.

Persons, J. (1997). Heterogeneous shareholders and signaling with share repurchases. Journal of Corporate Finance, 3, $221-249$.

Pettenuzzo, D., Sabbatucci, R., \& Timmermann, A. (2020). Dividend Suspensions and Cash Flow Risk during the COVID-19 Pandemic. Available at SSRN 3628608.

Pirgaip, B., \& Dinçergök, B. (2019). Share repurchases under uncertainty: U.S. evidence. Finance Research Letters, 30, $130-138$.

Ramelli, S., \& Wagner, A. (2020). Feverish Stock Price Reactions to Covid-19. CEPR.

Sheth, J. (2020). Business of business is more than business: Managing during the Covid crisis. Industrial Marketing Management, 88, $261-264$.

Şenocak, A., \& Ak, A. (2020, 04 27). The amount of cash dividends that can be distributed until 30 September 2020 shall not exceed $25 \%$ of the net profit generated in 2019;: Retrieved 06 22, 2020, from Gide Loyrette Nouel: https://www.gide.com/en/actualites/covid-19-new-legislation-mitigatingthe-impact-of-covid-19-on-economic-and-social-life-in

Vermaelen, T. (1981). Common stock repurchases and market signalings. Journal of Financial Economics, 9, $139-183$.

Vermaelen, T. (1984). Repurchase tender offers, signalling, and managerial incentives. Journal of Financial and Quantitative Analysis, $19,163-181$.

Zaremba, A., Kizys, R., Aharon, D., \& Demir, E. (2020). Infected Markets: Novel Coronavirus, Government Interventions, and Stock Return Volatility around the Globe. Finance Research Letters, 35.

Zhang, D., Hu, M., \& Ji, Q. (2020). Financial markets under the global pandemic of COVID-19. Finance Research Letters, In Press, Corrected Proof. Zhang, H. (2005). Share price performance following actual share repurchases. Journal of Banking \& Finance, $29(7), 1887-1901$.

\section{Figures}


Part A: Number of repurchasing firms and total amount of share repurchases (03.01.2020-22.04.2020)

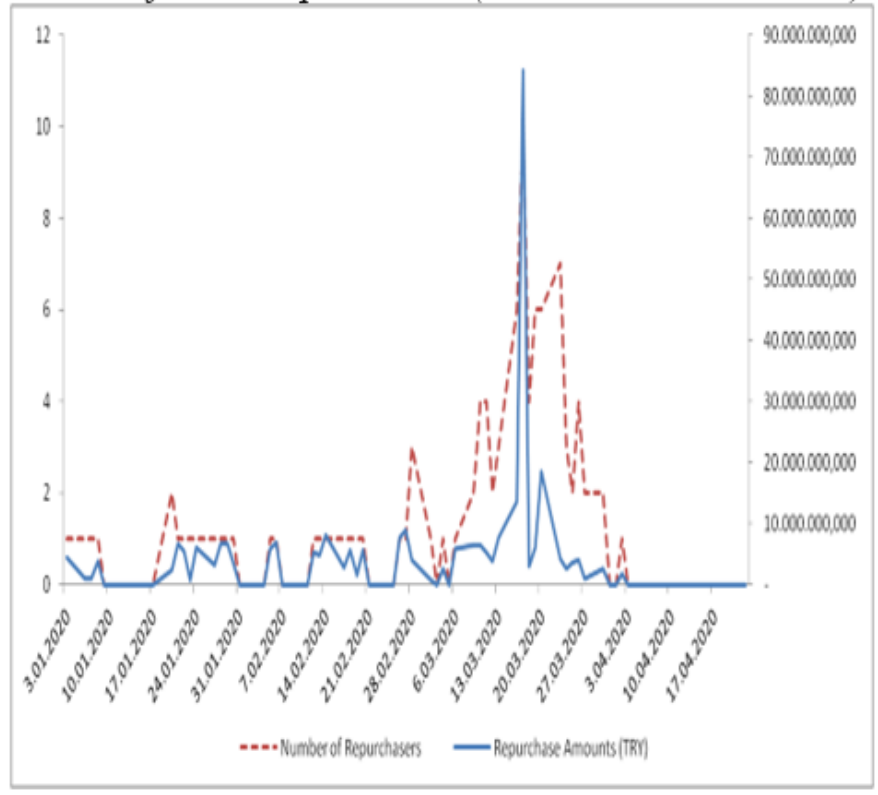

Part B: XU100 index and total amount of share repurchases (26.02.2020-08.04.2020)

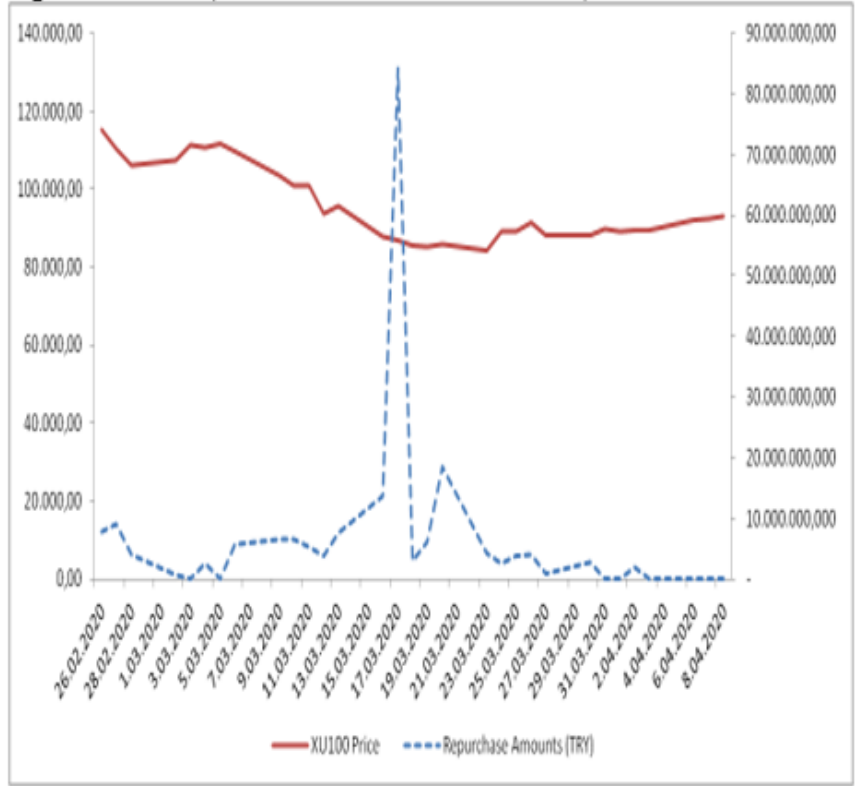

\section{Figure 1}

Repurchase transactions in Borsa Istanbul in Year 2020. Notes: Part A displays the graph of number of repurchasing firms (dotted line) as well as the total amount of share repurchases (solid line) in the period of 03.01.2020-22.04.2020. Part B graphically shows the total amount of share repurchases (dotted line) along with the course of XU100 (solid line) in the period of 26.02.2020-08.04.2020. A shorter period is used here in order to focus solely on "repurchasing" days.

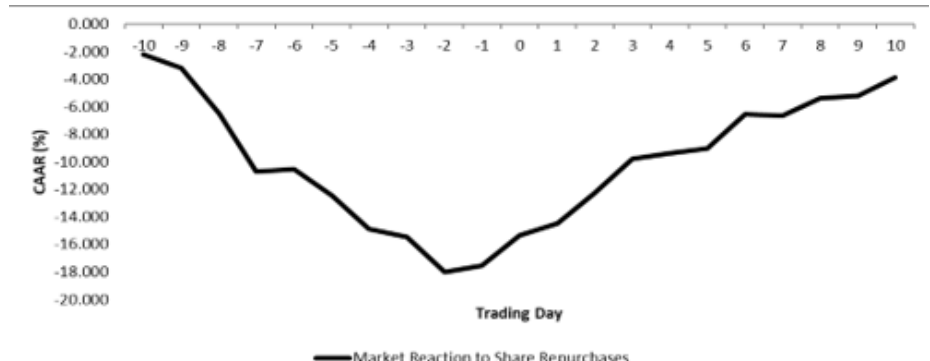

Figure 2

CAAR around the repurchase event Notes: This figure shows the evolution of CAAR, as an indicator of market reaction, around the repurchase event.

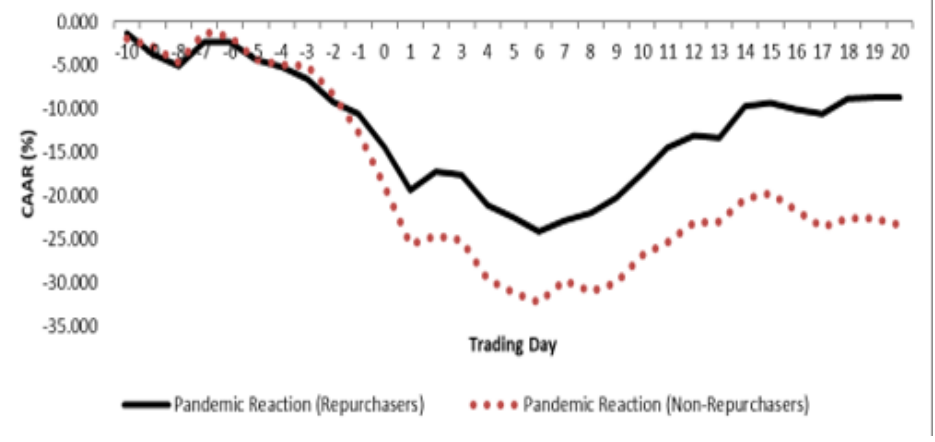

Figure 3

CAAR around the pandemic alert event Notes: This figure shows the evolution of CAAR of repurchasing firms (sold line) and CAAR of nonrepurchasing firms (dotted line), as an indicator of market reaction, around the pandemic alert event. 